\title{
The joint effect of democracy and economic freedom on
} corruption

\author{
Cristian Johan Picón Viana 1 \\ José Luis Ramos Ruiz ${ }^{2}$ \\ Camilo Almanza Ramírez 2 \\ José Luis Ramos Camargo ${ }^{3}$ \\ 1 Universidad de la Costa / Department of Business Sciences, Barranquilla - Colombia \\ 2 Universidad del Norte / Department of Economics, Barranquilla - Colombia \\ ${ }^{3}$ Universidad Simón Bolívar / Center of Business Growth \& Innovation (Macondolab), Barranquilla - Colombia
}

\begin{abstract}
This work examines the joint effect of democracy and economic freedom on corruption. The study used a database of 160 countries from 2010 - 2016, containing information for a set of economic, cultural, historical, and institutional variables. Several researches show that the joint effect of economic freedom levels and democracy are essential to fight corruption. Therefore, the most effective public policies for countries under study are those focused on the fundamental right of human beings to control satisfying outcomes of their jobs, which holistically encompasses the freedom and rights of production, distribution, or consumption of goods and services.
\end{abstract}

Keywords: corruption; economic freedom; democracy; fundamental right.

\section{Efeito conjunto da democracia e da liberdade econômica sobre a corrupção}

Este trabalho examina o efeito conjunto exercido pela democracia e pela liberdade econômica sobre a corrupção. Para tal fim, foram utilizados os bancos de dados de 160 países entre os anos de 2010 a 2016, considerando diversas fontes de informação para um conjunto de variáveis econômicas, culturais, históricas e institucionais. As pesquisas indicam que o efeito conjunto dos níveis de liberdade econômica e democracia é importante para combater a corrupção. Portanto, as políticas mais eficazes para os países analisados serão aquelas concentradas no direito fundamental dos seres humanos de controlar o resultado de seu trabalho, incluindo, de forma abrangente, as liberdades e os direitos de produção, distribuição ou consumo de bens e serviços.

Palavras-chave: corrupção; liberdade econômica; democracia; direito fundamental.

\section{Efecto conjunto de la democracia y libertad económica sobre la corrupción}

Este trabajo examina el efecto conjunto de la democracia y libertad económica sobre la corrupción. Para ello, se utilizan las bases de datos de 160 países de los años 2010 - 2016, considerando varias fuentes de información para un conjunto de variables económicas, culturales, históricas e institucionales. Las pesquisas señalan que el efecto conjunto de los niveles de libertad económica y democracia son importantes para combatir la corrupción. Por lo tanto, las políticas más eficaces para los países objeto de estudio, serán aquellas enfocadas al derecho fundamental que tienen los seres humanos para controlar el fruto de su trabajo, englobando de manera integral las libertades y derechos de producción, distribución o consumo de bienes y servicios.

Palabras clave: corrupción; libertad económica; democracia; derecho fundamental. 


\section{INTRODUCTION}

Corruption is one of the most widely studied phenomena, but one that is the most difficult to analyze. This is not only because of the anonymity of those involved, but also because of the difficulty of defining it and classifying activities as being corrupt or not. Despite the undeniable complicity of the private sector in corrupt actions, however, the approaches adopted by research into the subject have focused on corruption as a result of the interaction between the State and individuals who sacrifice collective well-being for their personal gain ${ }^{1}$. As a result they concentrate mainly on studying the unwanted actions of civil servants.

Corruption is a phenomenon of great importance to public administration. It is relevant insofar as it has a negative impact on a country's development ${ }^{2}$, reduces efficiency by increasing the expenditure of state-owned companies (Lopes, Câmara, Rocha, \& Brasil, 2018), distorts the structure of public spending (Caldas, Costa, \& Pagliarussi, 2016) and has an influence on the means of communication (Gehrke, Borba, \& Ferreira, 2017), among other aspects. Despite this, the scientific study of corruption diverges greatly with regard to the research methodologies and processes that should be followed.

Marani, Brito, Souza, \& Brito (2018) contribute to public administration studies when they identify different approaches to research into corruption and organize them into six groups, or thematic axes. One of the approaches they identified is that of carrying out research that deals with the perception, causes and effects of corruption, in which one of the fields that has advanced most with regard to these aspects is that of empirical cross-country studies into the determinants of corruption.

A large amount of research has been published since the mid-1990s, the purpose of which is to explain both theoretically and empirically the determinants of international corruption ${ }^{3}$, and to achieve great advances in the theoretical construction of this phenomenon. This is due, in large measure, to the development of Transparency International's Corruption Perception Index (CPI) in 1995. Variables such as economic prosperity, democratic institutions and the level of economic freedom are widely accepted as reducing corruption, but a number of aspects remain unresolved ${ }^{4}$; for example, the role that the interaction between these different determinants plays in the levels of corruption in a country.

Long the same lines, this article aims to answer the following questions: Does the interaction between levels of democracy and economic freedom need to be significant to better understand the phenomenon of corruption? Is this relationship between the joint effect of both determinants the same between groups in which there are different levels of corruption? To answer to these questions, the joint effects of democracy and economic freedom on levels of international corruption in 160 countries were estimated using a quantile regression model. This contributes to the object of the study to the extent that: the results expand knowledge with regard to the interdependence of the variables

\footnotetext{
${ }^{1}$ In this research, corruption is understood to be the abuse of public power for private gain (Klitgaard, 1988). For a discussion on the importance of the definition of corruption, see Lancaster and Montinola (1997); Philp, (1997); Tanzi (1998). See a detailed approach to the phenomenon of corruption in Svensson (2005).

${ }^{2}$ A framework for studying the relationship between governability and development can be found in Boeninger (1991). See Bardhan (1997) and Rose-Ackerman (1998) for discussions on the links between corruption and development.

${ }^{3}$ A search in Scopus for the word "corruption" in a title, resulted in 60 publications 1996. This number has increased constantly since then. The average number of publications a year between 2000 and 2019 was more than 370 articles.

${ }^{4}$ The key approaches to the importance of institutions to development and economic growth can be found in Rodrik, Subramanian, and Trebbi (2004) and in Rodrik (2002).
} 
indicated in the theoretical framework; there is greater rigor in specifying the study variables; and a greater number of countries are analyzed in which similar studies have been undertaken. ${ }^{5}$ The above makes it possible to show towards which aspects the policies and actions of public servants - who, as a principle, intend staying away from corruption - should be directed.

This paper is organized in five parts, including this introduction. In the second part, the conceptualization of the variables used and the results of previous research into the interaction between democracy and economic freedom are presented [Literature review]. The methodology used and the variables considered in the econometric model are then set out in the third section, while the results are analyzed and compared with the theoretical reality in the fourth part. Finally, the main conclusions are presented.

\section{LITERATURE REVIEW}

\subsection{Research antecedents}

Despite general agreement about the impact of institutional factors such as economic freedom and democracy on corruption, there is little scientific information on the "joint effect of these variables" and their impact on different levels of corruption. An advance in this matter was made by Saha, Gounder, and Su, (2009) who evaluated the interactive effect of democracy and economic freedom as determinants of corruption by analyzing panel data for 100 countries for the period $1994-2004$. The results show that while economic freedom reduces corruption in any political environment, it is more effective if there is a higher level of democracy. Democracy, therefore, can lead to an increase in corruption if economic freedom is low, and it will only reduce corruption above a certain threshold of economic freedom.

Along the same lines, in a publication with objectives that are similar to those in this research, Saha and Su, 2012 use data taken from Saha et al. (2009) to carry out an in-depth analysis of the joint effect of the levels of economic freedom and democracy on corruption using a quantile regression model. The results corroborate previous results and suggest that democratic and economic freedoms alone cannot effectively eliminate corruption in the most corrupt nations.

The joint effects of democracy and economic freedom as determinants of corruption, however, are not theoretically explained in the studies referred to above. ${ }^{6}$ In the first instance, as can be

\footnotetext{
${ }^{5}$ The main reference is the study by Billger and Goel (2009) who contributed to the literature on the determinants of corruption when they analyzed the conditional distribution of this phenomenon between countries by way of a quantile regression model using a sample of 99 countries. They found that in the most corrupt countries greater economic freedom does not seem to reduce corruption, but more democracy seems to lessen it, while the size of the State is ambiguous. They did not, however, use relevant variables from a theoretical viewpoint, such as religion and colonial origin. Neither was the specification of some of the variables adjusted, as will be explained later. Another important study is the one by Saha and $\mathrm{Su}$ (2012), in which the joint effect of levels of economic freedom and democracy on corruption was analyzed using a quantile regression model. This study, however, is not well defined from the theoretical viewpoint, as will be explained later.

${ }^{6}$ The general model used for these two studies is $\mathrm{CPI}_{\mathrm{i}}=\beta_{0}+\beta_{1} \mathrm{DEMO}_{\mathrm{i}}+\beta_{2} \mathrm{EF}_{\mathrm{i}}+\beta_{3} \mathrm{DEMO}_{\mathrm{i}} \mathrm{EF}_{\mathrm{i}}+\beta_{4} \log \left(\mathrm{RGDP}_{\mathrm{i}}\right)+\beta_{5} \mathrm{GINI}_{\mathrm{i}}+$ $\beta_{6} \mathrm{UNEM}_{\mathrm{i}}+\beta_{7} \mathrm{ALR}_{\mathrm{i}}+\varepsilon_{\mathrm{i}}$, where CPI is the corruption perception index, DEMO is the level of democracy, and EF is the arithmetic average of the "Business Freedom", “Trade Freedom", "Monetary Freedom", "Government Size", "Fiscal Freedom", "Property Rights", "Investment Freedom" and "Financial Freedom" indicators of the Economic Freedom Index published by The Heritage Foundation and The Wall Street Journal. The final four terms are real Gross Domestic Product per capita (RGDP), the GINI Index of Incomes (GINI), the unemployment rate (UNEM) and the adult literacy rate (ALR) and $\varepsilon$ is the error term.
} 
seen in Viana (2011), variables such as the literacy rate are highly correlated with the per capita income of countries, which suggests that the results are statistically invalid because of problems of multicollinearity. Secondly, the theoretical explanation of the relationship between unemployment and inequality on levels of corruption is not clear.

This work, therefore, helps clarify the subject not only because it uses a larger number of countries, but also a better theoretical specification of the variables, which enables the joint effects of the institutional factors of interest to be better isolated. It is important to use variables that are better supported in the theory of corruption, based on decades of empirical study. The main agreements that support the choice of variables used in this research and evidence with regard to the different determinants of corruption used in this type of cross-country study are briefly explained below.

\subsection{Determinants of corruption}

Most cross-country studies on corruption take as their point of reference hypotheses about the causes of corruption presented in La Porta, Lopez-de-Silanes, Shleifer, and Vishny (1999) and Treisman (2000). These authors propose links between incentives for those who face up to potentially corrupt people and the moral, legal, and institutional systems in which they operate. Based on these assumptions, they developed a set of functional relationships that allow some of the historical and socioeconomic characteristics of the countries to be identified as determinants of their levels of corruption. Empirical literature has subsequently been developed to test the evidence of this approach, thereby enriching it and developing a widely accepted theory of corruption (Pellegrini \& Gerlagh, 2007).

Along the same lines, based on Serra (2006) and Dreher, Kotsogiannis, and McCorriston (2007), it is possible to classify the determining variables of corruption into four groups:

Group 1 Economic variables: Studies generally consider the impact of a country's economic development and the size of its government on levels of corruption (Lambsdorff, 2007). A relatively large state can have a negative affect on levels of corruption due to increased bureaucracy, increased inefficiency, and disincentives to competition (Lambsdorf, 2006). State action, such as higher levels of regulation and discretionary fiscal policies, may benefit private partners or be transferred directly to the public employee (Tanzi, 1998).

On the other hand, empirical evidence suggests that the higher the level of economic prosperity, the lower the level of corruption (Lambsdorf, 2006; Picón \& Boehm, 2019; Serra, 2006). Economic development increases the spread of education, literacy, and entrepreneurship, each of which is likely to increase the likelihood that a corrupt act will be noticed (Treisman, 2000).

Group 2: Political and economic institutions: This group contains the explanatory variables related to the characteristics of the political regime of countries, and to their levels of economic freedom and democracy. The hypothesis is that levels of corruption in countries are positively correlated with their deficiencies in these aspects, because of they find it difficult to create transparent and competitive processes (Sandholtz \& Koetzle, 2000). 
Economic freedom comprises a set of economic and legal policies that encourage international trade and finance, the liberation of the capital market, and internal competition between companies that is free of state restrictions. There is ample evidence to show that higher levels of economic freedom and, therefore, greater competition, reduce levels of corruption among countries, thanks to the fact that they reduce the ability of public servants to monopolize goods and services because they are supplied by the market (Lambsdorf, 2006).

The concept of democracy in literature is associated with a particular set of institutions, such as free and fair elections, the accountability of politicians to voters and free entry into politics (Acemoglu \& Robinson, 2005). The hypothesis is that institutions in which these aspects are absent concentrate public power in certain groups, which facilitates manipulation of the norms and rules of the game of the economic system (Lambsdorff, 2007). Likewise, democratic institutions favor freedom of association and of the press and, therefore, the creation of public interest groups that hinder corrupt activities.

Group 3: Historical variables: Empirical literature shows that a country's past has an influence on the efficiency and effectiveness of its legal system and to what extent it permits corrupt situations. One of the most widely used historical variables for explaining levels of international corruption is the colonial past of countries.

Evidence suggests that those countries that were British colonies received a positive influence on their democratic traditions and judicial institutions (Brown, 2000; Lange, 2003; Mahoney, 2003). This would result in currently lower levels of corruption. These assumptions, however, have been refined, the emphasis now being on more specific aspects for explaining inherited colonial aspects, such as the quality of public administration and political institutions in the colonial period (Jones, 2013). Therefore, it is to be expected that the mere fact of being a British colony will become les significant in quantitative analyses as the number of countries is increased and, therefore, the variability of their historical characteristics.

Group 4: Cultural variables: This group contains a set of variables, such as values, beliefs and cultural aspects that might have an influence on corruption levels by influencing the socially accepted hierarchical structures and the legal system in each country. Most studies have focused on the impact of religious beliefs as an important foundation of social attitudes and family values. They propose that those religions that are most rigid in their structure tend to favor preservation of the status quo and, therefore, may be more tolerant of corruption. It has, therefore, been argued that Protestant Christianity, because it is less hierarchical than other religions, is less likely to tolerate abuses of power. The Protestant church also has a long tradition of separation from the State and has played a role in opposing abuses by political hierarchies (Treisman, 2000). In fact, various studies have found that the percentage of Protestants to the total population is a good predictor of levels of corruption (Pellegrini \& Gerlagh, 2007; Sandholtz \& Koetzle, 2000; Treisman, 2000). 


\section{METHODOLOGY}

\subsection{Definition of the variables}

The model's variables are shown in Table 1, where the dependent variable is Corruption, and the determining variables - taken from the literature review on the subject - are: Economic Variables [Economic Prosperity and Size of the State]; Economic and Political Institution Variables [Democracy and Economic Freedom]; Historical Variable [British Colony]; and finally, Cultural Variable [the Protestant Church]. The proposed variables are explained below.

\subsubsection{Corruption}

The Corruption Perception Index (CPI), published by Transparency International (and the most widely employed in this type of study) was used to measure corruption, multiplied by -1 to indicate that the index increases as the level of corruption increases. The inclusion of a single corruption index is justified because of the high correlation between the CPI and other indicators ${ }^{7}$ (Alesina \& Weder, 2002), and the fact that those agents that participate in their generation often represent organizations that generate other indicators of corruption.

On the other hand, for years there has been theoretical discussion about the relevance of perception indexes as indicators of corruption (Dreher et al., 2007). One of the most frequently heard arguments concerns the influence that access to information about cases of corruption can have, the perception being that they are overestimated when they are more visible and underestimated when they are not. This may be true in some corruption perception barometers, but in the case of the CPI the perception is taken from internationally respected institutions, business people from different countries and experts on the subject. ${ }^{8}$ Therefore, less media influence and less visible corrupt events (scandals) might be expected. The above is evident when we observe the relationship between the level of democracy and freedom and the perceived corruption as measured by the CPI; in a democratic environment there is greater freedom of the press and people have more access to information, but the evidence shows that they have lower levels of perceived corruption. In conclusion, the CPI can be considered to be a robust indicator and, therefore, it has stood the test of time.

\subsubsection{Determinants of corruption}

In accordance with the summarized classification of this research, we have:

[1] Economic variables: The average Gross Domestic Product per capita, 2010-2016, was used as an indicator of economic prosperity for the 160 countries as estimated by the Purchasing Parity Power [PPP] at 2011 prices. The main source of information was the World Bank's database. In the case of

\footnotetext{
${ }^{7}$ The "Corruption Control" index reflects a statistical compilation of responses to surveys on the quality of public management carried out in a large number of companies, and with citizens and experts, according to reports from a group of study institutes, non-governmental organizations and international organizations.

${ }^{8}$ Information about the CPI methodology for measuring can be easily checked on the web page of Transparency International. Retrieved from https://www.transparency.org.
} 
North Korea, an approximation was used by extrapolating the results of Maddison (2001) ${ }^{9}$, because this country does not produce any official statistics on its aggregate production or income. As an indicator of the size of the State, the proportion of public spending on GDP used in Billger and Goel (2009) was replaced by the government spending index, published by The Heritage Foundation and The Wall Street Journal ${ }^{10}$. According to the methodology, the scale of this index is not linear, which means that countries whose levels of public spending exceed 30\% of GDP are penalized, so that only really large governments receive very low scores.

\section{TABLE $1 \quad$ VARIABLES, THE OBJECT OF STUDY: CORRUPTION}

\begin{tabular}{|c|c|}
\hline VARIABLES & DESCRIPTION / SOURCES \\
\hline Corruption & $\begin{array}{l}\text { The Corruption Perceptions Index [CPI], published by Transparency International, } \\
\text { average } 2010-2016 \text {. Multiplied by }-1 \text { to indicate that the index increases as the } \\
\text { level of corruption increases. Normalized variable with a mean of } 0 \text { and a standard } \\
\text { deviation of } 1 \text {. } \\
\text { Source: CPI published by Transparency International. }\end{array}$ \\
\hline & [1] Variable: Economic \\
\hline 1.1. Economic prosperity & $\begin{array}{l}\text { Gross Domestic Product per capita, average 2010-2016. Estimated by PPP at } 2011 \\
\text { prices. In the case of North Korea, an approximation was used (Maddison, 2001). } \\
\text { Normalized variable with a mean of } 0 \text { and a standard deviation of } 1 \text {. } \\
\text { Source: World Bank, Central Intelligence Agency (CIA) and United Nations } \\
\text { Development Programme (UNDP).. }\end{array}$ \\
\hline 1.2. Size of the state & $\begin{array}{l}\text { Government Expenditure component of the Index of Economic Freedom. Average } \\
\text { 2010-2016. Normalized variable with a mean of } 0 \text { and a standard deviation of } 1 \text {. } \\
\text { Source: Published by The Heritage Foundation and The Wall Street Journal. }\end{array}$ \\
\hline \multicolumn{2}{|r|}{ [2] Variable: Economic \& Political Institutions } \\
\hline 2.1. Economic freedom & $\begin{array}{l}\text { Index of Economic Freedom. The average of the following indicators is taken into } \\
\text { account: "Business Freedom", "Labor Freedom", "Monetary Freedom", "Trade } \\
\text { Freedom", "Investment Freedom" and "Financial Freedom". Average 2010-2016. } \\
\text { Normalized variable with a mean of } 0 \text { and a standard deviation of } 1 . \\
\text { Source: Calculation based on indices published by The Heritage Foundation and The } \\
\text { Wall Street Journal (2010-2014). }\end{array}$ \\
\hline
\end{tabular}

\footnotetext{
${ }^{9}$ According to the CIA, North Korea does not publish National Income Accounting data; the data published by this entity is derived from purchasing power parity (PPP), using estimates of North Korea's GDP made by Angus Maddison in an OECD study; its 1999 figure was extrapolated to 2010-2016 using estimated real growth rates for North Korea’s GDP and an inflation factor based on the United States GDP deflator; results are approximately US $\$ 10$ billion.

${ }^{10} \mathrm{~A}$ list of studies on the interaction between corruption and size of the State can be found in Lambsdorff (2007).
} 


\begin{tabular}{|c|c|}
\hline VARIABLES & DESCRIPTION / SOURCES \\
\hline 2.2. Democracy & $\begin{array}{l}\text { Average of the political liberty and civil liberty indicators of "The Freedom in the } \\
\text { World" index. Average 2010-2016. Multiplied by }-1 \text { to indicate that the index } \\
\text { increases as the level of democracy increases. Normalized variable with a mean of } 0 \\
\text { and a standard deviation of } 1 \text {. } \\
\text { Source: Published by Freedom House. }\end{array}$ \\
\hline & [3] Variable: Historical \\
\hline 3.1. British colony & $\begin{array}{l}\text { Dichotomous variable; has a value of } 1 \text { if the country was a British colony; } 0 \text { if it was } \\
\text { not. } \\
\text { Source: Central Intelligence Agency (The World Factbook). Additional information for } \\
\text { this study can be found at: http://www.worldstatesmen.org/COLONIES.html\#British }\end{array}$ \\
\hline & [4] Variable: Cultural \\
\hline 4.1. Protestants & $\begin{array}{l}\text { Proportion of people who belong to the Christian Protestant church in each country } \\
\text { according to information available in 2014. Normalized variable with a mean of } 0 \text { and } \\
\text { a standard deviation of } 1 \text {. } \\
\text { Source: Central Intelligence Agency (The World Factbook) and the Religious Freedom } \\
\text { Report, provided by the US State Department. }\end{array}$ \\
\hline
\end{tabular}

Source: Elaborated by the authors.

[2] Economic \& Political Institution Variables: In accordance with Billger and Goel (2009) ${ }^{11}$ in order to measure these variables we propose using the Index of Economic Freedom [IEF], as published by The Heritage Foundation and The Wall Street Journal ${ }^{12}$. However, the authors include indicators corresponding to "Public spending" and "Tax freedom" in the IEF, which, since they represent the level of government spending, would generate strong correlation problems [multicollinearity] between the previous explanatory variables and the "Government size" variable, which corresponds to the ratio of public spending to GDP ${ }^{13}$. In the specific case of this study, which is more faithful to the definition of economic freedom, the 2010-2016 average of the following indicators of the IEF were considered: Business Freedom, Labor Freedom, Monetary Freedom, Trade Freedom, Investment Freedom and Financial Freedom. As a result, the multicollinearity problems discussed above were avoided, which allowed more countries to be included.

As in Billger and Goel (2009), this study proposes the "Freedom in the World" index as an indicator of the level of democracy in the countries studied. Each country is assigned the 2010-2016 average of the sum of the "Political freedoms" and "Civil liberties" indicators of the index, multiplied by $(-1)$ to indicate that the index increases as the level of "democracy" increases.

[3] Historical variable: A dichotomous variable is used as a historical factor that takes the value 1 if the country was a British colony and 0 if it was not. This variable was generated from information

\footnotetext{
${ }^{11}$ Billger and Goel (2009) include only economic and institutional factors in their analysis. This study expands upon this when it takes into account the other determining aspects of corruption that were identified in the literature on the topic.

${ }^{12}$ For details, see http://www.heritage.org

${ }^{13}$ This decision reached ambiguous conclusions about the role of the size of the state on the levels of corruption arrived at in this research.
} 
made available by the United States Central Intelligence Agency - CIA (The World Factbook) and additional information published by the World Statesmen organization.

[4] Cultural Variable: In this study, the proportion of Protestants in each country is taken as the cultural variable, according to information for 2014. This variable was generated from the information available from the CIA in the United States (The World Factbook) and found in the Religious Freedom Report, provided by the United States Department of State.

\subsection{Data and model}

With regard to the data, the cross-sectional information of 160 countries was used. For all the quantitative variables - with the exception of the "Protestant" variable - the average of the data corresponding to the 2010-2016 interval was used to reduce the effects of short-term variations. They were normalized with a mean of 0 and a standard deviation equal to 1 , in order to allow for a correct analysis, regardless of the scales presented by the different indicators. ${ }^{14}$

For the first time, countries like North Korea and some African countries, which because of a lack of data have traditionally been excluded from most analyses, are included. ${ }^{15}$ To achieve the research objectives, a quantile regression model was used, by which the determinants of corruption can be carefully examined throughout the conditional distribution, with special attention being paid to the least and most corrupt countries. ${ }^{16}$. A detailed explanation of this type of regression is developed in Cameron and Traveti (2010), along with a guide to its application using STATA software.

According to Koenker and Bassett (1978), a general model of quantile regression is as follows:

$$
y_{i}=\sum \beta_{j}^{(q)} x_{i j}+\varepsilon_{i}^{(q)}
$$

Where $0<\mathrm{q}<1$ indicates the proportion of the population with scores below the qth quantile. Therefore, for each observation error $\varepsilon_{i}$ will be:

\footnotetext{
${ }^{14}$ The interval is due to the availability of data for the countries included. The data were standardized to facilitate their handling, since their significance does not change due to this action, but all the variables are represented on the same scale. Despite being within the possibilities, a panel data model was not carried out because the objectives of the research require the determinants of corruption to be analyzed throughout the distribution. In other words, comparing more corrupt countries with less corrupt countries; the quantile regression model is ideal for this (Billger \& Goel, 2009).

${ }^{15}$ Some of the African countries included are Lesotho, The Gambia, Sierra Leone, and Swaziland, which are usually not included in this type of study because of a lack of data.

${ }^{16}$ It is important to clarify that this model is not causal. It is a regression model and therefore does not really reflect causation. However, it is not a simple correlation model either; regression models analyze variables asymmetrically. In other words, a dependent variable is assumed that presents a probability distribution, while independent variables are considered to be fixed in repeated theoretical samples. This means that regression models are linked to a theory that supports the choice of one of the variables as dependent. In this case, the dependent variable is corruption in the different countries, which is assumed to be dependent on a set of determining variables. Therefore, specification of the model must be in accordance with what the theory supports, thanks to the experience of many researchers who have contributed to the study of corruption. This is this work's main criticism of studies like that of Saha et al. (2009) and the main contribution it makes. On the other hand, from a theoretical point of view, the direction of the causality is not a priority in this study: for example, corruption cannot be said to have an impact on historical variables; facts such as corruption having a negative impact on democracy, or on the level of economic prosperity do not influence recommendations as to where public policies should be directed.
} 


$$
\varepsilon_{i}^{q}=y_{i}-\sum_{j} \beta_{j}^{(q)} x_{i j}
$$

Therefore, a regression for a specific quantile $q$ th (where $q \in(0,1)$ ) is the solution for:

$$
\min \left[\sum_{i \in\left\{i: y_{i} \geq x^{\prime}{ }_{i} \beta\right\}} q\left|y_{i}-x^{\prime}{ }_{i} \beta\right|+\sum_{i \in\left\{i: y_{i} \leq x^{\prime}{ }_{i} \beta\right\}}(1-q)\left|y_{i}-x^{\prime}{ }_{i} \beta\right|\right.
$$

This problem is solved using linear programing techniques. The algorithm is taken from Hunter and Lange (2000), and was processed using the STATA statistical software with the "sqreg" command, which estimates a simultaneous regression for the indicated quantiles and obtains an estimate of the covariance matrix by bootstrapping. The general model is specified in the following way:

$$
C P I_{i}=\beta_{0}+\beta_{1} \mathrm{DEMO}_{i}+\beta_{2} \mathrm{EF}_{i}+\beta_{3} \mathrm{DEMO}_{i}{ }^{*} E F_{i}+\beta_{4} \mathrm{GDP}_{i}+\beta_{5} \mathrm{GS}_{i}+\beta_{7} \mathrm{COL}_{i}+\beta_{6} \mathrm{PROT}_{i}+\varepsilon_{i}
$$

wher $\beta_{3} \mathrm{e}$ is the joint effect of the level of democracy and economic freedom on corruption. The results of this model are comparable to those obtained by way of a simple linear regression.

\section{RESULTS}

Table 2 shows the results of two specifications. The first corresponds to the specification without the joint effect of economic freedom and democracy, while the second, has the joint effect. An OLS linear regression model and a quantile regression model are used in both specifications.

\section{TABLE 2 DETERMINANTS OF CORRUPTION - ORDINARY LEAST SQUARES [OLS] REGRESSION AND} REGRESSION QUANTILES, 2010-2016

\begin{tabular}{lcccccc} 
Variables & MC0 & Q10 & Q25 & Q50 & Q75 & Q90 \\
\hline First specification & & & & & & \\
\hline Economic prosperity & $-0.434^{\star \star \star}$ & $-0.464^{\star \star \star}$ & $-0.567^{\star \star \star}$ & $-0.500^{\star \star \star}$ & $-0.398^{\star \star \star}$ & $-0.318^{\star \star \star}$ \\
& $(-7.50)$ & $(-4.61)$ & $(-6.25)$ & $(-4.32)$ & $(-4.34)$ & $(-3.63)$ \\
\hline Size of the State & $0.145^{\star \star \star}$ & $0.208^{\star}$ & 0.095 & $0.115^{\star}$ & 0.108 & 0.040 \\
& $(3.10)$ & $(1.86)$ & $(1.38)$ & $(1.83)$ & $(1.63)$ & $(0.62)$ \\
& & & & & & Continue
\end{tabular}


RAP | The joint effect of democracy and economic freedom on corruption

\begin{tabular}{|c|c|c|c|c|c|c|}
\hline Variables & MCO & Q10 & Q25 & Q50 & Q75 & Q90 \\
\hline \multirow{2}{*}{ Protestants } & $-0.123^{\star \star \star}$ & -0.061 & $-0.103^{\star \star}$ & $-0.091^{*}$ & -0.077 & -0.028 \\
\hline & $(-3.51)$ & $(-0.62)$ & $(-2.14)$ & $(-1.74)$ & $(-1.05)$ & $(-0.32)$ \\
\hline \multirow{2}{*}{ British colony } & -0.050 & 0.045 & -0.012 & -0.064 & -0.204 & 0.001 \\
\hline & $(-0.63)$ & $(0.22)$ & $(-0.13)$ & $(-0.65)$ & $(-1.47)$ & (0) \\
\hline \multirow{2}{*}{ Democracy } & $-0.254^{\star \star \star}$ & -0.185 & $-0.261^{\star \star \star}$ & $-0.259^{\star * *}$ & $-0.309^{\star * *}$ & $-0.224^{* \star \star}$ \\
\hline & $(-5.14)$ & $(-1.46)$ & $(-4.55)$ & $(-4.05)$ & $(-4.13)$ & $(-4.49)$ \\
\hline \multirow{2}{*}{ Economic freedom } & $-0.283^{\star \star \star}$ & $-0.400^{\star \star \star}$ & $-0.272^{\star \star \star}$ & $-0.237^{\star \star \star}$ & $-0.194^{\star \star \star}$ & $-0.255^{\star \star \star}$ \\
\hline & $(-5.60)$ & $(-3.00)$ & $(-4.06)$ & $(-2.93)$ & $(-2.97)$ & $(-4.37)$ \\
\hline \multirow{2}{*}{ Constants } & 0.013 & $-0.517^{\star \star \star}$ & $-0.257^{\star \star \star}$ & 0.033 & $0.343^{\star \star \star}$ & $0.569^{\star \star \star}$ \\
\hline & $(0.30)$ & $(-4.40)$ & $(-5.42)$ & $(0.55)$ & (5.46) & (10.48) \\
\hline \multicolumn{7}{|l|}{ Second specification } \\
\hline \multirow{2}{*}{ Economic prosperity } & $-0.396^{\star \star \star}$ & $-0.433^{\star \star \star}$ & $-0.427^{\star \star \star}$ & $-0.436^{\star \star *}$ & $-0.350^{\star * *}$ & $-0.264^{\star \star \star}$ \\
\hline & $(-7.68)$ & $(-3.55)$ & $(-4.26)$ & $(-4.2)$ & $(-4.43)$ & $(-3.12)$ \\
\hline \multirow{2}{*}{ Size of the State } & $0.089^{\star \star}$ & $0.173^{*}$ & 0.066 & 0.070 & 0.028 & 0.003 \\
\hline & (2.05) & (1.73) & (1.03) & (1.19) & $(0.45)$ & $(0.06)$ \\
\hline \multirow{2}{*}{ Protestants } & $-0.093^{\star \star \star}$ & -0.016 & -0.087 & $-0.083^{*}$ & -0.047 & 0.000 \\
\hline & $(-2.60)$ & $(-0.19)$ & $(-1.56)$ & $(-1.7)$ & $(-0.73)$ & (0) \\
\hline \multirow{2}{*}{ British colony } & -0.076 & -0.041 & -0.094 & -0.087 & -0.190 & -0.096 \\
\hline & $(-1.00)$ & $(-0.22)$ & $(-0.95)$ & $(-0.88)$ & $(-1.47)$ & $(-0.62)$ \\
\hline \multirow{2}{*}{ Democracy } & $0.408^{\star \star}$ & $0.750^{\star}$ & 0.268 & $0.429^{\star}$ & 0.358 & 0.372 \\
\hline & (2.22) & $(1.83)$ & $(0.85)$ & (1.72) & (1.34) & $(1.24)$ \\
\hline \multirow{2}{*}{ Economic freedom } & $-0.606^{\star \star \star}$ & $-0.803^{\star \star \star}$ & $-0.558^{\star \star \star}$ & $-0.605^{\star \star \star}$ & $-0.554^{\star \star \star}$ & $-0.541^{\star \star \star}$ \\
\hline & $(-6.07)$ & $(-3.84)$ & $(-3.67)$ & $(-4.09)$ & $(-3.87)$ & $(-3.19)$ \\
\hline \multirow{2}{*}{ Joint effect } & $-0.564^{\star \star \star}$ & $-0.770^{\star \star}$ & $-0.494^{\star}$ & $-0.580^{* *}$ & $-0.558^{\star \star}$ & $-0.491^{\star \star}$ \\
\hline & $(-3.63)$ & $(-2.17)$ & $(-1.81)$ & $(-2.59)$ & $(-2.43)$ & $(-2.02)$ \\
\hline \multirow{2}{*}{ Constants } & 0.019 & $-0.553^{\star \star \star}$ & -0.219 & 0.008 & $0.333^{\star \star \star}$ & $0.555^{\star \star \star}$ \\
\hline & $(0.47)$ & $(-5.21)$ & $(-4.27)$ & $(0.14)$ & (5.63) & (10.99) \\
\hline
\end{tabular}

Source: Calculations elaborated by the authors (2018).

Notes: The dependent variable is the Corruption Perception Index (Corruption in Table 1).

The model comprises a sample of 160 countries with up-to-date data for the 2010-2016 period.

All the variables were normalized with the median 0 and standard deviation 1 .

The results of the regression quantiles are based on 1000 bootstrap repetitions.

The smallest quantiles (Q10 for example) represent countries with smaller indices of perceived corruption.

The absolute values of the statistic $t$ appear in parentheses. $\left.{ }^{* * *}\right),\left({ }^{* *}\right)$ and $\left({ }^{*}\right)$ denote significant coefficients at the $0.01,0.05$ and 0.1 levels, respectively. 
In the first instance, we observe that the indicator of economic prosperity is strongly significant for all specifications (between higher levels of prosperity and lower levels of corruption). In other words, this explains that economic prosperity is a determining variable for reducing corruption, which is calculated in average terms by quantiles as for the whole distribution. In other words, higher levels of income correspond to lower levels of corruption in the different countries, regardless of whether they are highly corrupt, or not very corrupt countries. The theory suggests that this result is due to the importance of education levels, better health, and citizen independence with regard to the public power that is generated as the population grows richer.

With regard to Size of the State, it is significant in average terms (larger governments increase levels of corruption), but it is not consistent throughout the different quantiles and loses its importance when the joint effect of the institutional variables is isolated. It is only somewhat significant for the least corrupt countries. In other words, the least corrupt countries run the risk of their position deteriorating as the size of the state increases. The same is true for countries that are in the intermediate corruption group.

On the other hand, the proportion of Protestants is significant in average terms according to the OLS regressions, which confirms the findings of the literature that was analyzed. Countries are less corrupt, on average, when there are more Protestants as a proportion of their total population. However, when analyzing the different quantiles, we observe that this result is not consistent throughout the distribution, since it is only relevant in those countries located in the least corrupt quantile (Q10).

As for having been a British colony, this variable is not significant on average by OLS, or taking into account the entire conditional distribution using regression quantiles. One possible explanation is the size of the sample; by including corrupt countries and those that had been once colonized by the British Empire, which had not been taken into account in previous studies, the evidence that colonization by England is a good indicator of low corruption seems to have become clouded. Subsequent studies should emphasize institutional inheritance and type of colonization rather than simply the simplistic assumption of colonial origin.

With regard to the variables of interest to the objectives of this paper, when analyzing the results and, unlike the findings of Billger and Goel (2009) and Saha and Su (2012), the economic freedom indicator is strongly significant in average terms and for the entire quantile distribution, even when the joint effect with democracy is isolated. This shows that countries with more economic freedom are significantly less corrupt. ${ }^{17}$ This effect is stable for the whole distribution, but is most important for the quantile of least corrupt countries. Likewise, the level of democracy is relevant when analyzing the average effects by OLS. It is not, however, of great significance in the rest of the distribution once the joint effect with the level of economic freedom is isolated. This seems to indicate that simply moving to a higher level of democracy does not necessarily help improve the situation in terms of corruption; that is, moving from group with more corruption to a group with less corruption. The data show, however, two breakpoints: deteriorating in terms of the levels of democracy when in the group (quantile) of less corrupt countries could increase levels of corruption within the group, and might even relegate the country to a group with the worst level of corruption. We observe the same

\footnotetext{
${ }^{17}$ As indicated previously, the reasons for these differences are due to the fact that in this work a better specification of the models is made according to the theory, better use is made of the indices as institutional variables, and the base of countries is much broader.
} 
for countries in the intermediate quantile. Therefore, democracy analyzed in isolation is relevant only for these groups.

Up to this point, the evidence shows that higher levels of economic freedom determine lower levels of corruption and that higher levels of democracy are not sufficient for reducing corruption in most cases. To better understand the behavior of these variables, however, their behavior needs to be analyzed once their joint or interactive effect has been isolated. The results show that the joint effect of the institutional variables (Democracy $y^{\star}$ and Economic Freedom) has a negative impact on levels of corruption, both in average terms and in quantiles. These results coincide with Saha et al. (2009), when they state that the union of economic freedom and democracy generates more effective results for reducing corruption.

In this sense, the results obtained by isolating the joint effect of the institutional variables indicate that levels of democracy lose significance in the different quantiles. This means that greater democracy is relevant to lower levels of corruption only when accompanied by higher levels of economic freedom. Along the same lines, we find a preponderance of the level of economic freedom, because this variable is still very significant, despite isolating the interactive effect with democracy.

\section{CONCLUSIONS}

This study responds to the following questions:

Does the interaction between levels of democracy and economic freedom need to be significant to better understand the phenomenon of corruption? The answer is yes. By isolating the joint effect of the variables of interest, we found that greater democracy is relevant for reducing levels of corruption only to the extent that it is accompanied by higher levels of economic freedom and that the latter's levels reduce corruption even after the joint effect with democracy is isolated.

Is this relationship between the joint effect of both determinants the same between groups in which there are different levels of corruption? Again, the answer is yes. The results show that the joint effect of the institutional variables (Democracy ${ }^{\star}$ and Economic Freedom) has a negative impact on levels of corruption, both in average terms and in quantiles; in other words, regardless of the level of corruption in a country that is the subject of the policy.

In short, we have shown that an increase in economic freedom and democracy are, on average, key tools for reducing corruption. The results of the quantile regression, however, show that these derivations are not consistent across the different levels of corruption. When the joint effect of the level of democracy and economic freedom is isolated, levels of democracy become less important. This indicates that policies for reducing and preventing corruption that tend to increase levels of democracy will be effective only to the extent that they are accompanied by greater levels of economic freedom. Along the same lines, the indicator variable of economic freedom was found to be very significant, despite isolating the interactive effect with democracy. Therefore, the most effective policies will be those that focus on greater economic freedom, which means the fundamental right that human beings have to control the result of their work, comprehensively encompassing the freedoms and rights of production, distribution or the consumption of goods and services. 


\section{REFERENCES}

Acemoglu, D., \& Robinson, J. A. (2005). Economic origins of dictatorship and democracy. Cambridge, UK: Cambridge University Press. Retrieved from https://doi.org/10.1017/CBO9780511510809

Alesina, B. A., \& Weder, B. (2002). Do Corrupt Governments Receive Less Foreign Aid? The American Economic Review, 92(4), 1126-1137.

Bardhan, P. (1997). Corruption and Development: A Review of Issues. Journal of Economic Literature, 35(3), 1320-1346. Retrieved from https://doi. org/10.4324/9781315126647-30

Billger, S. M., \& Goel, R. K. (2009). Do existing corruption levels matter in controlling corruption?. Cross-country quantile regression estimates. Journal of Development Economics, 90(2), 299-305. Retrieved from https://doi.org/10.1016/j.jdeveco.2008.07.006

Boeninger, E. (1991). Governance and development: issues and constraints. In L. H. Summers \& S. Shah (Eds.), World Bank annual conference on development economics (pp. 267-287). Washington, D.C.: World Bank.

Brown, D. S. (2000). Democracy, colonization, and human capital in sub-Saharan Africa. Studies in Comparative International Development, 35(1), 20-40. Retrieved from https://doi.org/10.1007/ BF02687449

Caldas, O. V., Costa, C. M., \& Pagliarussi, M. S. (2016). Corrupção e composição dos gastos governamentais: Evidências a partir do Programa de Fiscalização por Sorteios Públicos da Controladoria-Geral da União. Revista de Administracao Publica, 50(2), 237-264. Retrieved from https://doi.org/10.1590/00347612140185

Cameron, A. C., \& Traveti, P. K. (2010). Microeconometrics Using Stata. College Station, TX: Stata Press Publication.

Dreher, A., Kotsogiannis, C., \& McCorriston, S. (2007). Corruption around the world: Evidence from a structural model. Journal of Comparative Economics, 35(3), 443-466. Retrieved from https:// doi.org/10.1016/j.jce.2007.07.001

Gehrke, G., Borba, J. A., \& Ferreira, D. D. M. (2017). A repercussão da corrupção brasileira na mídia: Uma análise comparada das revistas Der Spiegel,
L'Obs, The Economist, Time e Veja. Revista de Administracao Publica, 51(1), 157-167. Retrieved from https://doi.org/10.1590/0034-7612158681

Hunter, D. R., \& Lange, K. (2000). Quantile Regression via an MM Algorithm. Journal of Computational and Graphical Statistics, 9(1), 60-77. Retrieved from https://doi.org/10.1080/10618600. 2000.10474866

Jones, P. (2013). History matters: New evidence on the long run impact of colonial rule on institutions. Journal of Comparative Economics, 41(1), 181200. Retrieved from https://doi.org/10.1016/j. jce.2012.04.002

Klitgaard, R. (1988). Controlling Corruption ( $1^{\text {st }}$ ed.). Berkeley, CA: University of California.

Koenker, R., \& Bassett, G. (1978). Regression Quantiles. Econometrica, 46(1), 33. Retrieved from https://doi.org/10.2307/1913643

La Porta, R., Lopez-de-Silanes, F., Shleifer, A., \& Vishny, R. W. (1999). The Quality of Government. Journal of Law, Economics, \& Organization, 15(1), 222-279.

Lambsdorf, J. G. (2006). Causes and consequences of corruption: What do we know from a cross-section of countries? In S. Rose-Ackerman (Ed.), International Handbook on the Economics of Corruption (pp. 3-51). Montpellier, UK: Edward Elgar Publishing Limited.

Lambsdorff, J. G. (2007). The institutional economics of corruption and reform: Theory, evidence, and policy. In J. G. Lambsdorff (Ed.), The Institutional Economics of Corruption and Reform: Theory, Evidence, and Policy. Cambridge, UK: Cambridge University Press. Retrieved from https://doi. org/10.1017/CBO9780511492617

Lancaster, T. D., \& Montinola, G. R. (1997). Toward a methodology for the comparative study of political corruption. Crime, Law and Social Change, 27(3-4), 185-206. Retrieved from https:// doi.org/10.1023/A:1008274416350

Lange, M. (2003). Embedding the Colonial State: A Comparative-Historical Analysis of State Building and Broad-Based Development in Mauritius. Social Science History, 27(3), 397-423. Retrieved from https://doi.org/10.1215/01455532-27-3-397 
Lopes,E. P., Jr., Câmara, S. F., Rocha, L. G., \& Brasil, A. (2018). Influência da corrupção nos gastos das empresas estatais. Revista de Administração Pública, 52(4), 695-711. Retrieved from https://doi. org/10.1590/0034-7612173631

Maddison, A. (2001). The World Economy: A Millennial Perspective. Paris, Francia: OCDE Publications.

Mahoney, J. (2003). Long-Run Development and the Legacy of Colonialism in Spanish America. American Journal of Sociology, 109(1), 50-106. Retrieved from https://doi.org/10.1086/378454

Marani, S. C. Z., Brito, M. J., Souza, G. C., \& Brito, V. G. P. (2018). Os sentidos da pesquisa sobre corrupção. Revista de Administração Pública, 52(4), 712-730. Retrieved from https://doi.org/10.1590/00347612175197

Pellegrini, L., \& Gerlagh, R. (2007). Causes of corruption: A survey of cross-country analyses and extended results. Economics of Governance, 9(3), 245-263. https://doi.org/10.1007/s10101-007-0033-4

Philp, M. (1997). Defining political corruption. Political Studies, 45(3), 436-460. Retrieved from https://doi.org/10.4324/9780429448072-2

Picón, C., \& Boehm, F. (2019). Do the determinants of corruption differ between countries with different levels of corruption? A cross-country quantile regression analysis. Revista de Economía Del Caribe, 23, 71-83. Retrieved from https://doi.org/10.14482/ rec.v0i23.11982

Rodrik, D. (2002, Feb.). Institutions, integration, and geography: in search of the deep determinants of economic growth. Retrieved from http://j. $\mathrm{mp} / 2 \mathrm{oGu} 20 \mathrm{~g}$

Rodrik, D., Subramanian, A., \& Trebbi, F. (2004). Institutions rule: The primacy of institutions over geography and integration in economic development. Journal of Economic Growth, 9(2), 131-165. Retrieved from https://doi.org/10.1023/ B:JOEG.0000031425.72248.85
Rose-Ackerman, S. (1998). Corruption and Development. In B. Pleskovic \& J. Stiglitz (Eds.), Annual World Bank Conference on Development Economics (pp. 35-57). Washington, D.C.: World Bank.

Saha, S., Gounder, R., \& Su, J.J. (2009). The interaction effect of economic freedom and democracy on corruption: A panel cross-country analysis. Economics Letters, 105(2), 173-176. Retrieved from https://doi.org/10.1016/j.econlet.2009.07.010

Saha, S., \& Su, J. J. (2012). Investigating the Interaction Effect of Democracy and Economic Freedom on Corruption: A Cross-Country Quantile Regression Analysis. Economic Analysis and Policy, 42(3), 389-396. Retrieved from https://doi. org/10.1016/S0313-5926(12)50036-6

Sandholtz, W., \& Koetzle, W. (2000). Accounting for corruption: Economic structure, democracy, and trade. International Studies Quarterly, 44(1), 31-50. Retrieved from https://doi.org/10.1111/00208833.00147

Serra, D. (2006). Empirical determinants of corruption: A sensitivity analysis. Public Choice, 126(1-2), 225-256. Retrieved from https://doi. org/10.1007/s11127-006-0286-4

Svensson, J. (2005). Eight questions about corruption. Journal of Economic Perspectives, 19(3), 19-42. Retrieved from https://doi. org/10.1257/089533005774357860

Tanzi, V. (1998). Corruption Around the World. Imf Staff Papers, 45(4), 559-594. Retrieved from https:// doi.org/10.2307/3867585

Treisman, D. (2000). The causes of corruption: a cross-national study. Journal of Public Economics, 76, 399-457.

Viana, C. P. (2011). Aplicación de un modelo predictivo de clasificación basado en redes neuronales. Revista de Economía Del Caribe, 8. Retrieved from http://www.scielo.org.co/pdf/ecoca/ n8/n8a02.pdf 


\section{Cristian Johan Picón Viana}

https://orcid.org/0000-0002-7300-6089

Masters degree in Economics from the Universidad del Norte; PhD student in Social Sciences (Becario Colciencias); Teacher and researcher in the Department of Economic Sciences at the Universidad de la Costa (CUC). E-mail: cpicon@cuc.edu.co

\section{José Luis Ramos Ruiz}

https://orcid.org/0000-0002-8659-6604

Doctor in Economic, Sociology \& Agrarian Policy from the Universidad Politécnica de Valencia (Spain); Full professor of the Department of Economics and a researcher with the Economic Analysis Group of the Universidad del Norte (Barranquilla - Colombia).E-mail: jramos@uninorte.edu.co

\section{Camilo Almanza Ramírez}

https://orcid.org/0000-0003-3934-5578

Doctor in Economics from the Friedrich-Alexander University, Erlangen-Nuremberg (Germany); Professor in the Department of Economics and a researcher for the Economic Analysis Group of the Universidad del Norte (Barranquilla - Colombia).E-mail: almanza@uninorte.edu.co

\section{José Luis Ramos Camargo}

https://orcid.org/0000-0002-0460-4480.

MSc in Management (Innovation) from Brighton University (England); Professor and researcher in the Business Growth \& Innovation Center [MACondolab] of the Universidad Simón Bolívar (Barranquilla-Colombia). E-mail: jose.ramos@unisimonbolivar.edu.co 